\title{
THE MADNESS OF THE EMPEROR CALIGULA
}

(Gaius Julius Caesar Germanicus)

by

\author{
A. T. SANDISON, B.Sc., M.D. \\ Department of Pathology, the University and Western Infirmary, Glasgow
}

ThR OUG HOUT the centuries the name of Caligula has been synonymous with madness and infamy, sadism and perversion. It has been said that Marshal Gilles de Rais, perhaps the most notorious sadist of all time, modelled his behaviour on that of the evil Caesars described by Suetonius, among whom is numbered Caligula. Of recent years, however, Caligula has acquired his apologists, e.g. Willrich; so also, with more reason, has the Emperor Tiberius, whose reputation has been largely rehabilitated by modern scholarship.

Our knowledge of the life of Caligula depends largely on Suetonius, whose work De vita.Caesarum was not published until some eighty years after the death of Caligula in A.D. 4I. Unfortunately that part of Tacitus's Annals which treated of the reign of Caligula has been lost. Other ancient sources are Dio Cassius, whose History of Rome was written in the early third century and, to a lesser extent, Josephus, whose Antiquitates Fudaicae was published in A.D. 93, and Philo Jadaeus, whose pamphlet Legatio ad Gaium and In Flaccum may be considered as contemporary writings. It seems probable that all these ancient sources are to some extent prejudiced and highly coloured. Suetonius's Gaius Caligula in De vita Caesarum is full of scabrous and sometimes entertaining stories, on some of which little reliability can be placed.

Nevertheless, the outlines of Caligula's life-history are not in doubt, and a useful summary is given by Balsdon (1949) in the Oxford Classical Dictionary. Caligula was born in Antium on 3 i August A.D. 12, the son of that popular prince, Germanicus Julius Caesar and of Agrippina. From the age of two to four years he was with the army on the Rhine frontier with his parents, and it is said that here he received his name 'Caligula' from the soldiers because of the miniature military boots that he wore. In A.D. 18-19 he accompanied his parents to the East. There Germanicus died in Antioch in A.D. I9 in rather mysterious circumstances, and Caligula returned to Rome with his mother. After her arrest and banishment to Pandateria by Tiberius, he lived with Livilla and Antonia, his grandmother, until A.D. 32, when Tiberius sent for him to join the imperial household on Capreae.

Caligula had been pontifex in A.D. $3^{I}$ and was quaestor two years later, but had held no other official position. Nevertheless, after the death of his brother Drusus in A.D. 33 he was declared co-heir to Tiberius along with Tiberius Gemellus, his nephew. On the death of Tiberius, Caligula was strongly supported by Macro, prefect of the Praetorians, and acclaimed sole Emperor on 


\section{The Madness of the Emperor Caligula}

I6 March A.D. 37. At first he spoke disrespectfully of Tiberius and paid honour to the shades of his dead parents and brothers. He appears to have ruled admirably, possibly under Antonia's influence. Antonia, however, died on I May A.D. 37. In October of the same year Caligula became seriously ill. Philo thought that his mind was unhinged as a result and to this concept we shall later return. After his recovery, he caused both Macro and Tiberius Gemellus to be put to death. He then quarrelled with the Senate, became entirely autocratic and changed his attitude to the memory of Tiberius, blaming the Senate for many of the faults attributed to the late Emperor. In the winter of A.D. 39-40 he went to Gaul and the Rhine, and possibly intended to invade either Germany or Britain. To this period belongs the story of Caligula ordering his troops to collect shells on the sea-shore. Certainly no large military operations were, in the end, undertaken. At about this time he forestalled a conspiracy on his life, led by Cornelius Lentulus Gaetulicus, who was thereafter executed. After his return to Rome he went in fear of assassination, governed with extreme cruelty and accepted extravagant honours approaching deification. He was responsible for great unrest among the Jews by a proposal to set up his image in the Temple of Jerusalem. He was murdered in his palace on 24 January A.D. 4I, along with his fourth wife Caesonia and his infant daughter and was succeeded by his uncle Tiberius Claudius Nero Germanicus. Of the accuracy of the above summary there can be little doubt.

Suetonius has said that Caligula, even in his nineteenth year, could not control his inherent cruelty and viciousness, was an eager witness of torture and execution and revelled in singing, dancing, gluttony and lechery. If the modern assessment of Tiberius's life on Capreae made, for example, by Marãnón (1956) is accepted, however, it is difficult to reconcile this with Seutonius's description of the young Caligula on Capreae.

Among the allegations made by Suetonius is that after the death of Tiberius, Caligula lived in habitual incest with all his sisters, especially with Drusilla, with whom he contracted some form of 'marriage'. It appears certain that he was greatly grieved when Drusilla died and caused her to be consecrated. Many modern authorities discount this story of incest. Suetonius also alleges that Galigula had homosexual relations in both roles, among others with Mnester, his actor favourite whom he embraced in public, and with Marcus Lepidus and Valerius Catullus. He is also said to have importuned and ravished many women of rank, selecting them at dinners and other social occasions in his palace, and that, when short of money, he opened a house of ill-fame in his palace, where both matrons and free-born youths were exposed for hire. Suetonius also claims that Caligula used to exhibit his beautiful wife Caesonia in a state of nudity to his friends. $\mathrm{He}$ is also said to have affected peculiar dress and sometimes wore women's clothing, including the garb of Venus, to have invited the Moon to his bed, to have talked to Jupiter Capitolinus and to have set up a temple to his own Godhead.

Among the atrocities listed by Suetonius are the feeding of criminals to the wild beasts when cattle became expensive, the branding of men of rank who 


\section{A. T. Sandison}

were also sometimes caged or sawn asunder. Other cruelties included the protraction of death by intermittent beating with chains or by many small wounds. He is said to have cut out a man's tongue to silence him before having him thrown to the beasts. He revelled in torture and execution while at table and openly gloried in his power to have anyone decapitated at his nod.

He cast down statues of famous men and deprived Rome's oldest and noblest families of their ancient devices, e.g. removed the surname of 'Magnus' from Gnaeus Pompeius. He denigrated the works of Homer, Virgil and Livy. He even had shaved the heads of men who showed fine growth of hair. 'There was no one of such low condition or such abject fortune that he did not envy him such advantages as he possessed.'

Suetonius described Caligula's personal appearance as tall and pale with a large body and thin legs. His head was bald but his body hirsute. He was sound neither in body nor mind: as a boy he was troubled with the 'falling sickness'. In youth he was at times unable to walk, stand up, collect his thoughts and to hold up his head. He was tormented by insomnia, never sleeping more than three hours at a time and experiencing vivid dreams. To this weakness there was added, paradoxically, extreme assurance but excessive timorousness so that he was afraid of thunder or lightning and even of the smoke from the crater of Mount Etna.

In his History of Rome, Dio Cassius emphasizes Caligula's essential contrariness, his madness, sadism and his incestuous tendencies. Josephus also presents Caligula in a less monstrous light, but shows him to be unbalanced in his mind by power.

If we turn now to modern commentators we find that Jerome (1923) emphasizes the unreliability of the testimony of Suetonius and Dio Cassius on the grounds that their accounts do not completely tally. He also suggests that the evidence of Philo Judaeus and Josephus is suspect because of the profound hatred engendered among the Jewish nation by Caligula's proposal to erect his statue in the Temple of Jerusalem. Jerome suggests that on his accession Caligula's conduct was exemplary and that this probably continued for about one year. He agrees that Caligula may have been an epileptic, but states that mania is rare in epileptics. It might be pointed out, however, that while true mania is rare, many epileptics are subject to states of exaltation and excitement not unlike true mania. Jerome suggests that alcoholism may have been partially responsible for Caligula's behaviour.

Charlesworth (1933, 1934) also questions the reliability of Suetonius and Dio Cassius on the grounds of inconsistency with inscriptional evidence and puts more reliance on Josephus. Charlesworth thinks that Caligula's atrocities possibly occurred only in the last year of his reign, and that they may have been engendered by fear and suspicion. It seems certain, however, that in the year A.D. 4o Rome experienced a reign of terror-a tyranny requiring men to flatter and be servile and in which the informant flourished. It cannot be doubted either, Charlesworth concedes, that Caligula envied eminence in any sphere of life. Charlesworth concludes that Caligula's life in the end was possessed by an insane self-exaltation. 


\section{The Madness of the Emperor Caligula}

Balsdon (1934) has given us a detailed and scholarly analysis of the life of Galigula, but to some extent this might be considered apologist. Balsdon thinks that Tiberius in the late years of his life was paranoid, but by no means the depraved debauchee portrayed by Tacitus and Suetonius. His companions on Capreae were educated Greeks and Chaldeans so that the notorious 'Spintrians' seem to vanish under the light of modern scholarship.

Balsdon ably minimizes many of the accusations made against Caligula and thinks that his serious illness may have been a 'nervous breakdown'. Balsdon points out the important fact that there was no popular hostile feeling against the Emperor until about January A.D. 4I, when new and much resented taxes were levied. He further suggests that Caligula's belief in his own divinity, his appearances dressed as Venus or Jupiter, the prostration of his subjects, the kissing of feet were the normal practices of Hellenistic monarchy. If this be true, it might be extended to include incest which occurred in the Ptolemaic family in Egypt. As for his interest in bloody spectacles, Balsdon makes the point that here he was at one with the entire Roman people.

Balsdon further suggests that Caligula was profligate only with his personal fortune and not with the State moneys. He is described by Balsdon as cultured, well educated and a literary critic with original views. His personal life displayed only in an exaggerated fashion the weaknesses of his time-prodigality, immorality, hedonism, cruelty and extravagance in all things. His rapid succession of four marriages Balsdon does not consider unusual, nor does he think it established that Caligula was guilty of incest. Nor does Balsdon believe that Caligula was a habitual drunkard, although it is admitted that he may have been epileptic. It is indeed difficult to understand Caligula's early popularity unless he were a normal and attractive personality at that time. Although Philo Judaeus believed that Caligula's illness in A.D. 37 altered his character radically, Balsdon points out that other authorities are not clear on this point. Josephus dated his change of character to A.D. 38 or 39 ; Balsdon goes so far as to consider that there was no clear-cut change and that he may never have been truly mad. He adduces his cruelty to fear following the plot on his life in A.D. 40. At the death of Caligula the populace were neither downcast nor exultant. In conclusion Balsdon thinks that the accounts of Suetonius and Dio Cassius were probably coloured by more recent political hatreds. He points out also that it is a great pity that Tacitus's account of Caligula's reign in the Annals has been lost and feels that it is probable that Tacitus considered him violent and tempestuous rather than mad.

As has already been mentioned, a recent monograph on Tiberius by Marãnón (1956) goes far to restore the reputation of that Emperor. Marãnón interprets the actions of Tiberius as being motivated by resentment and possibly influenced by his addiction to alcohol. Nevertheless Marãnón does not consider that Tiberius was mad, although he may have been of schizoid personality. It now seems probable that the scandalous stories of Tiberius on Capreae are fabrications and that Galigula probably behaved normally there. Marãnón believes that Caligula was undoubtedly mad-a typical epileptic from childhood with 


\section{A. T. Sandison}

fits and deliriums of cruelty and sexual aberration. It is well known that epilepsy tended to occur in the Julian family. Caligula's grandmother Julia was alleged to be epileptic as was also Agrippina II. Gaius Caesar, eldest son of Agrippa and Julia, was said to be mentally dull and melancholic while Agrippa Posthumus, third son of the same marriage was brutal, violent and depraved.

It is interesting to note in passing that Marãnón suggests that the Emperor Claudius, Caligula's uncle and successor, may have had encephalitis in childhood. There is no record of this, and it seems unlikely in view of Claudius's excellence as an administrator; it is conceded, however, that Claudius had a weak constitution and some form of paralysis, possibly congenital.

Ireland (1893) pointed out that sanity may be regarded as the result of education, and that those who cannot be educated to control their passions and subdue their appetites to the limits prescribed by society really grow up insane, i.e. have never had sanity implanted upon their natures. The effects of absolute power, such as Caligula enjoyed, lead from free indulgence in sensual pleasures to immoderate lust and debauchery to domination, contempt and pleasure in suffering to final derangement. Ireland points out that the Emperor Nero, being a better balanced personality, remained evidently normal until he had enjoyed several years of absolute power. While it is doubtful if Ireland's concept of sanity and insanity is valid, there is no doubt that the effects of absolute power in corrupting personality have been seen repeatedly in history. Not all Roman emperors, however, proved to be mad or debauched.

Kiefer (1934) in his monograph on sexual behaviour in classical Rome described Caligula as a tainted hereditary degenerate corrupted by absolute power, vile, coarse, mad and cruel. He cites Müller and Von Delius as regarding Caligula as a case of dementia praecox, who showed his first attack of dementia a few months after his accession.

In summary, of the ancient authors, Suetonius portrays Caligula as a perverted sadist who imagined himself divine; Josephus thought of him as a person unbalanced by absolute power, while Philo regarded him as affected mentally by his serious illness in A.D. 37. Of recent scholars, Jerome regards him as an alcoholic epileptic while Charlesworth considers Caligula's behaviour to be of paranoid type engendered by fear and suspicion; Balsdon also lays much stress on this state of fear and suspicion, possibly exacerbated by his illness which Balsdon considers may have been a 'nervous breakdown'. According to Balsdon, in contradiction to Jerome, Caligula was not an alcoholic but lived in a style reminiscent of Hellenistic monarchy. Marãnón regards Caligula as a mad epileptic with a bad family history while Ireland sees him as a man corrupted by power, for the acquisition of which he was ill-educated. So also does Kiefer, although he also lays stress on his hereditary degeneracy. Kiefer cites other authors as considering Caligula a case of dementia praecox. In passing we may also give some views on Tiberius. Balsdon regards him as a paranoid personality while Marãnón considers him as schizoid, a confirmed alcoholic but motivated by longstanding resentment, possibly originating in the 


\section{The Madness of the Emperor Caligula}

divorce of his mother Livia from Tiberius's father Claudius Nero in order that she might marry Octavian, who later became Augustus.

There is, therefore, considerable divergence of opinion among scholars as to the degree and nature of Caligula's abnormalities. That he was unbalanced for some years seems certain. It also seems reasonable to assume that his early popularity and the loyalty of the people on his accession must be regarded as evidence of his normality at that time. The statement of Philo Judaeus, who was a contemporary, that he was unbalanced by his illness is highly significant and cannot be disregarded. It would be improper, however, to ignore the question of undoubted epilepsy in the Julian family.

\section{The Medical Aspects of Caligula's Madness}

Among the causes to be considered may be numbered the sequelae of a bacterial meningitis, cerebral neoplasia possibly affecting the frontal regions, cerebro-vascular disease, general paralysis of the insane, dementia praecox, epilepsy or post-encephalitic change.

It seems improbable that Caligula's illness in A.D. 37 was a bacterial meningitis. Severe meningitis may leave residual mental defects but without treatment is likely to prove fatal. Nor is it at all likely that cerebral neoplasm was implicated since apparent recovery took place. Caligula's age rules out the possibility of cerebro-vascular degenerative disease. General paralysis of the insane may also be excluded as it is virtually certain that syphilis was unknown in Europe in pre-Columbian times. Dementia praecox is unlikely since Caligula showed considerable 'drive'.

It is known that in epileptics changes of mood characterized by surliness and irritability may precede the attacks, and that epileptic psychoses may be independent of the attacks. In these epileptic psychoses there may be hallucinations, great fear and sometimes religious ecstasy. Epileptics generally may be irritable, suspicious, egotistic and show the devoutness of religiosity. Walshe (1943) has said that 20 per cent of epileptics may become deranged. Epileptics rarely become schizoid but may not uncommonly show a paranoid type of picture. While the possibility of epilepsy cannot be discarded in some respects a post-encephalitic picture seems more probable. Some importance may be attached to Suetonius's statement that Caligula suffered from severe insomnia and from vivid dreams. Insomnia may, of course, be the result of anxiety, grief, mental conflict or alcoholism, but in these conditions is rarely intractable. Inveterate insomnia, however, may follow an attack of acute encephalitis but is not a feature of epilepsy.

Other post-encephalitic disabilities include alterations in character and conduct: even an apparently slight initial encephalitis may be followed by profound progressive disorder of motor or mental type. Von Economo (193I) has pointed out that epileptic states and epilepsy may follow encephalitis lethargica, as may, especially in young persons, moral degeneration and hypomania. These changes may occur also in adults and are thought to be due to the removal of inhibitory influences. Among other mental changes described 


\section{A. T. Sandison}

by Von Economo are hallucinatory paranoid states, with intact consciousness and without confusions, and delusions of persecution. While Parkinsonism is usually noted in adults this is by no means invariable.

It is well known that encephalo-myelitis may complicate many virus diseases, e.g. influenza, measles, rubella, chickenpox, mumps, smallpox and psittacosis, as well as other conditions such as whooping-cough, scarlatina, chorea typhus and relapsing fever. In the latter condition there is presumably activation of a latent virus. True epidemic encephalitis is, however, a distinct disease entity and is sometimes known as encephalitis lethargica. For valuable and compendious works on this disease reference may be made to Von Economo (I93I) and the Surveys of the Matheson Commission (1929, 1932). Although the condition was first recognized as an entity and named by Von Economo it has undoubtedly occurred for many centuries. In Europe over the past four to five centuries epidemics of schlafkrankheit or nona have been described and these have undoubtedly been outbreaks of epidemic encephalitis. The disease occurs often in the colder months of the year and affects males more frequently. The incidence is not related to social conditions. Epidemics have been described in Italy, and one occurring in Rome itself in the winter of 1919-20 numbered 338 cases, of which 124 occurred in the age group $21-40$ years.

For an historical study of epidemic encephalo-myelitis reference may be made to Crookshank (1922). In this paper it is suggested that encephalitis may well have occurred in Hippocratic times.

Conclusions. It seems to be certain that Caligula, during the later years of his reign, showed undoubted mental derangement characterized by selfdeification, sadism, perversion, great extravagance, pathological envy, possibly some degree of paranoid change, intractable insomnia and vivid dreams. It is probable that at the time of his accession Caligula's personality was normal, and it is certain that he suffered a severe illness at the age of twenty-five years. Philo Judaeus believed that thereafter his mind was unhinged. This seems entirely possible and not improbable. If this is accepted then we may speculate on the nature of this illness. It is suggested that this may have been epidemic encephalitis which is known to produce mental changes not inconsistent with those which have been described in Caligula. Epidemic encephalitis is known to occur in Rome and, while it was first recognized as a clinico-pathological entity fairly recently it has certainly occurred in Europe over several centuries and may well have been present in Hippocratic times.

\section{ACKNOWLEDGEMENTS}

I am indebted to Professor D. F. Cappell, to Dr. J. McHarg and to Dr. J. Swanson Beck for criticism of this manuscript.

\section{REFERENCES}

Balsdon, J. P. V. D. (1934), The Emperor Gaius (Caligula), Oxford.

Balsdon, J. P. V. D. (1949), The Oxford Classical Dictionary, Oxford Clarendon Press, p. 375. 208 


\section{The Madness of the Emperor Caligula}

Charlesworth, M. P. (1933), 'The Tradition about Caligula', Camb. hist. F., rv, ro5.

Gharlesworth, M. P. (1934), 'Gaius and Claudius', Chapter 20 in Cambridge Ancient History, Cambridge, vol. $\mathbf{x}$.

Grookshank, F. G. (I922), 'Influenza'; essays by several authors, Chapter 5, London, Heinemann.

Dio Cassius, Roman History.

Ireland, W. W. (1893), 'The Blot upon the Brain', Paper IV, Chapter 1, Edinburgh, Bell and Bradfute.

Jerome, T. S. (1923), Aspects of the Study of Roman History, Chapter 18, New York and London, Putnam.

Jose phus, Antiquitates Fudaicae.

KIEFER, O. (1934), Sexual Life in Ancient Rome, translated by G. \& H. Highet, London, Routledge.

Marãnón, G. (1956), Tiberius: a Study in Resentment, London.

Matheson Commission (1929, 1932), Report of a Survey of Epidemic Encephalitis, New York, Columbia University Press.

Philo Judaeus, Legatio ad Gaium, E In Flaccum.

Surtonius, 'Gaius Caligula' in De vita Caesarum.

Von Eсомомо, C. (1931), Encephalitis Lethargica: Its Sequelae and Treatment, translated by K. O. Newman, London, Oxford University Press.

W Alshe, F. M. R. (1943), Diseases of the Nervous System, Edinburgh, Livingstone.

The ancient sources may readily be consulted in the Loeb Classical Library Series, published by Heinemann, London, where an English translation is given in parallel. A popular translation of Suetonius by Robert Graves appeared in Penguin Books in 1957. 